\title{
Online Learning as a Panacea for Dealing with School Truancy
}

\author{
Francisca N. Nnajiofor \\ Department of Vocational Education, Faculty of Education, Nnamdi Azikiwe University \\ Awka, Nigeria. E-mail: nnajinebe@yahoo.com
}

Joseph C. Onyilagha (corresponding author)

Department of Biology, University of Arkansas at Pine Bluff, 1200 North University Drive, Mail Slot 4972, Pine Bluff, AR 71601, USA. E-mail: onyilaghaj@uapb.edu

Received: February 6, 2016 Accepted: March 4, 2016 Published: April 14, 2016

doi:10.5296/jet.v3i2.8983ＵRL: http://dx.doi.org/10.5296/jet.v3i2.8983

\begin{abstract}
School truancy has been identified as one of the causes of students' low school achievement, leading to school dropout. Although the problem of school truancy is not new, yet, many school authorities or Governments have no rules on how to deal with this problem. In some arears, there is apparently no database or information, and educators are at a loss as to whether school truancy exists, and at what level if it does. There is no coordinated action against school truancy in many school districts. Consequently, each school district takes decision on how it approaches the problem. This study is designed to have a conversation directly with the student clientele and to determine what they know about school truancy, and from their perspective offer suggestion(s) or strategies that would help to reduce or prevent school truancy. Results suggest for a distinction between "school truancy" and "class truancy" in order to help school managers to adequately focus on each group rather than treating "skipping school" and "skipping classes" with the same amount of resources. The study suggests giving incentives to good students, providing adequate school bus services, insisting on "no $12^{\text {th }}$ grade, no drivers license", and putting several classes online would be good prevention strategies. The above excerpt forms the basis of the research results presented in this paper.
\end{abstract}

Keywords: School truancy, online learning, prevention strategy 


\section{Introduction}

School truancy is a tendency of the child to skip schools. McCray (2006) describes truancy as the act of staying away without permission. The causes, effects and prevention strategies of school truancy have attracted the attention of many scholars in the field of education. Several research papers have appeared on the subject (Fremont, 2003; Henry, 2007; Mueller \& Stoddard, 2006; Reimer \& Dimock, 2005). While some researchers (Brandibas, Jeunier, Clanet, \& Fouraste, 2004) have focused efforts on the attempt to understand this problem, others (Reid, 2004; Stover, 2005; Teasley, 2004) have consciously looked into avenues that would help to reduce or prevent the upward movement of this problem.

Reducing or preventing this problem requires a true understanding or definition of truancy. There is no central definition or yardstick to measure who is, and who is not a truant. State laws vary regarding the definition of truancy. In South Carolina, for example, a student who misses three consecutive days of school without an excuse, or five days altogether, is considered a truant (Smink \& Heilbrunn, 2005). Colorado defines a truant as having more than ten unexcused absences in an academic year, or four or more unexcused absences in one month (Christie, 2006). Some States insist on distinguishing between a habitual and a simple truant. In the case of a simple truant, the student is an occasional, mischievous class cutter; the habitual truant misses several days of classes. Against this backdrop, missing up to three days of classes in Wisconsin, for example, is considered "simple truancy", while missing between three and ten days is considered habitual truancy. These inconsistencies and/or variations in definitions create confusion and make a national accurate statistical documentation very cumbersome. Nevertheless, school refusal, simple or habitual truancy is a serious problem to many families and school districts in the United States (Fremont, 2003; Henry, 2007), and requires a concerted approach in tackling this seemingly national epidemic.

Reimer and Dimock (2005) identify school truancy as an educational, social, and juvenile justice issue worthy of public and private attention. Henry (2007) reports that the Office of Juvenile Justice and Delinquency Prevention (OJJDP) takes school truancy as a serious concern that affects most school districts in the United States. Despite the seriousness of this problem, there is still no accurate estimate of truancy in the United States. The lack of accurate statistics may be due to inconsistent tracking and reporting practices of schools (Henry, 2007), or due to differences in defining what truancy means. The inability to document the rate of school truancy may pose significant challenges in our desire or attempts to start solving the problem. Available statistics is sketchy, and show that in some States or cities, for example, in New York City, about 150,000 out of 1,000,000 students are absent daily, and school officials are unsure what portion of the absences are legitimately excusable. The Los Angeles Unified School District reports that 10 percent of its students are absent each day, while in Detroit 66,440 truant complaints were investigated during the 1994-95 school year (Ingersoll \& LeBoeuf, 1997). In the 1996 report of the United States Department of Education, about 3,500 students or 12 percent of the pupil population in Pittsburgh miss school each day and about 70 percent of these absences are unexcused. In Philadelphia, approximately 2,500 students a day are absent without an excuse, and in Milwaukee, approximately 4,000 unexcused absences occur each day in schools. 
Research indicates that the processes that lead to school truancy are cumulative, which makes them difficult to pin down (Beekhoven \& Dekkers, 2005). They suggest that truancy among school children may be as a result of one or a combination of factors such as socioeconomic, family background and individual's general cognitive development and/or perception about schooling. Truant students tend to display some similar characteristics. For example, they lack personal and educational ambition. They have poor academic performance, lack of self-esteem, and have unmet mental health needs, and most likely to indulge in alcohol and drug use and abuse. A clinical diagnosis of the characteristics of a truant may be useful in our understanding of the behavior model and a possible remedial therapy. Fremont (2003), though distinguishes between school refusal and truancy, suggests that children who refuse going to school are associated with "comorbid psychiatric disorders", such as anxiety and depression. A close resemblance between school refusal and truancy may prompt a clinical diagnosis of school truants.

Truancy among school children has many implications to the student, family, school district, and the society. It impacts negatively on student's academic achievement and school programs. Fantuzzo, Grim, and Haxan (2005) suggest that school truancy has reached epidemic proportion with far reaching consequences and negative implications for multiple levels of the society. For example, truancy has been linked to many problem behaviors such as academic failures, school dropout, and juvenile delinquency (Mueller \& Stoddard, 2006; Reimer \& Dimock, 2005). Studies indicate that students with chronic absenteeism have less opportunities to learn and, have low achievement potential (McCray, 2006). Report from the National Center for Education Statistics indicate that student access to education is directly related to time spent in the classroom. Smink and Heilbrunn (2005) suggest that attendance has economic implications for schools. On one hand, most schools are funded based on attendance during "count day" or "count week." On the other hand, truant students are expensive to educate; they use more counselor time, generate more disciplinary referrals, and require more instructional and support staff.

Prevention of truancy is a complex task. Fremont (2003) suggests a combination of collaborative approaches by family physician, school staff, parents, community, and mental health professionals. On many occasions, truancy prevention efforts are typically school-based, court-based, or community-based. The best efforts would be to incorporate all three components that will provide a continuum of prevention and intervention strategies. Truancy reduction programs that involve incentives and consequences for good, improved, and poor attendance would be useful. Also, collaboration among schools, families, communities, school administrators, teachers, courts, law enforcement agencies, social services providers, businesses, faith-based and youth-serving agencies would be very helpful. Effective record keeping to track improvements in student attendance and truancy rates is needed in schools.

In some jurisdictions within the United States and indeed, many parts of the world, there are no databases or records of school truancy and its prevention strategies. Consequently, programs for truancy prevention are apparently the responsibility of the school districts. It is alarming that many students are "falling through the cracks and using the home school law to 
circumvent the system and not get an education". There is need for a well-documented and centralized approach in dealing with school truancy. Such a statewide approach would give leverage to the school districts as they contemplate making truancy rules or planning for programs in their respective schools.

\section{General Overview}

The inconsistencies that have trailed the subject, "school truancy", may not be surprising to scholars working in the area. In fact, the problem with its prevention may be associated with lack of its proper definition or delineation, and many workers tend to confuse truancy with school dropout. For example, McCray (2006) defined truancy as "the act of staying away without permission". However McCray did not define the number of times a student or any individual can stay away before being described as a truant. This prompted Christie (2006) to ask the salient question, "at what point are students who choose not to attend school found to be truants?" No adequate responses have been given to this question, and confusion on the subject continues to grow. In the State of Arizona, for example, a student is a truant if he/she misses a class period during a school day without permission. In California, truancy is taken to be when a student is absent without valid excuse for three full days in one school year, or absent for more than any 30-minute period during a single school day, or three occasions in one school year, or a combination thereof. The State of Colorado treats truancy as four unexcused absences in one month or ten unexcused absences during any school year. Epstein and Sheldon (2002) made it more complicating as they seem to focus on students who leave schools prior to graduation rather than on daily student attendance. This treatment is synonymous to school dropout. Fremont (2003) goes further to introduce the term "school refusal", and tries to draw a distinction between this terminology and school truancy. He argues, among other reasons, that while children who refuse to go to school have interest at schoolwork and complies with completing schoolwork at home, the truant lacks interest in schoolwork and unwilling to conform to academic and behavior expectations. Contrary to Fremont's views, Brandibas, Jeunier, Clanet, and Fouraste (2004) retain their definition of school truancy as a "refusal to attend school in relation to different types of anxiety". Although these differences exist with respect to definitions, however, there seem to be a consensus of opinion on the effects of school truancy.

As already mentioned earlier, school truancy has negative effects on the student, family, school district and the Nation. Reglin (1997) reports that truancy is highly correlated with low levels of school achievement and high drop-out rates. Fantuzzo and co-workers (Fantuzzo, Grim, \& Haxan, 2005) note that truancy has far reaching consequences, resulting in negative implications for multiple levels of the society. Other workers share similar notion that school truancy leads to delinquency (Baker, 2000; Hallfors et al., 2002). Hallfors and co-workers go further to show that truancy leads to substance abuse, while Hibbert and Fogelman (1990) demonstrate the associative outcome of teenage pregnancy. These serious and/or adverse effects have led school districts, governments, the community, and other stakeholders to start articulating the best ways to curb the problem. 
Several propositions have been put forward in an effort to finding the best possible solution to school truancy. In this task, McNear (1999) proposes parental involvement, while Smink and Heilbrunn (2005) put forward measures such as the establishment of school attendance review boards to bring together families, school and community representatives that may include mental health specialists, department of human services staff, and other community members. Smink and Reimer (2005) suggest that truancy prevention requires a multimodal program and propose fifteen strategies to tackle this problem. These strategies include among others, collaboration, use of incentives and sanctions, mentoring, family involvement, and establishment of a supportive context. In line with these several suggestions, some Counties have established legal agencies to deal with the problem. For example, Escambia County in Northwest Florida established the Truancy Court Conference Program (TCCP) in 1993 to monitor, document and process school truants (Reglin, 1997). However, Bazemore, Stinchcomb, and Leip (2004) are not in support of involving the Justice Departments in the control of school truancy. Contributing to the debate, Henry (2007) notes that apart from parental involvement, interventions designed to improve engagement in school and/or improve safety at school may help to reduce truancy. Several writers (Reid, 2004; Stover, 2005; Teasley, 2004) have written extensively on truancy prevention strategies, and many more new strategies are yet to be formulated. There is urgent need for new workable strategies to prevent or reduce school truancy because there is evidence that the number of students missing school continues to defy the best practices presently in place (Reid, 2004).

\section{Materials and Methods}

In view of the foregoing, we decided to use the focus group method over a three-year (2012 2015) period to probe groups of university sophomore students on their understanding of "school truancy", and best workable strategies to prevent it. A total of 190 students participated in the focus group discussions during the three-year period. Participation was purely voluntary. The following five questions were posed to the students during each meeting:

a. How would you describe the term, "school truancy?"

b. Do you know of any reason or reasons why students skip school or classes?

c. How aware are you of the adverse effects of school truancy?

d. If you were in position of authority, what would you do to stop school truancy?

e. What would be your advice to school authorities on how to stop school truancy?

Each student was given a copy of the questions and asked to write answers below each question. Student responses were collected immediately after the session and scored.

\section{Results}

Responses to each of the five questions are shown below. Percent of student participants who give the same or similar responses are given in brackets. 


\begin{tabular}{rr} 
Macrothink & Journal of Education and Training \\
Institute & ISSN 2330-9709 \\
TM & 2016, Vol. 3, No. 2 \\
\hline
\end{tabular}

a. How would you describe the term, "school truancy?"

skipping school (45\%)

skipping classes (40\%)

late to school (10\%)

other definitions (5\%)

b. Do you know of any reason or reasons why students skip school or classes?

hate going to school or no interest (30\%)

ignorance (25\%)

scared of some students (17\%)

parents don't care (13\%)

may not want to take a scheduled quiz (10\%)

others (5\%)

c. How aware are you of the adverse effects of school truancy?

very aware (51\%)

aware (37\%)

limited awareness (10\%)

not aware (2\%)

d. If you were in position of authority, what would you do to stop school truancy?

give incentives to good students (35\%)

provide adequate school bus services to schools (29\%)

no $12^{\text {th }}$ grade, no driver's license (18\%)

shorter school hours (10\%)

others (8\%)

e. What would be your advice to school authorities on how to stop school truancy?

put classes online (55\%)

have a conference with parents and students (28\%)

suspend erring students from school (12\%)

others $(5 \%)$ 


\section{Discussion}

Results show that students are aware of the school truancy problem and could offer suggestions on how to curb this epidemic. Students define school truancy as either skipping school or skipping classes (question \#1). This type of definition is confusing and mirrors the confusion that trails the definition in several school districts. This definition brings to light as to whether a "class cutter" is truly a school truant. Christie (2006) suggests that an occasional class cutter is a simple truant, while a habitual truant misses several days of classes. Our view is that a class cutter may be in school, but skips some classes for whatever reasons. Is it right to regard such a student as a truant since he/she is in school? Is it necessary to distinguish between "class truant" and "school truant?" Obviously, there is need to make this distinction in order to properly define and address the problem of school truancy.

Perhaps one important outcome of this work may be seen in students' responses in questions "d \& e" above. Among other suggestions in question "d", students are of the view that completing the $12^{\text {th }}$ grade should be a condition for having a driving license. In other words, one has to attend school in order to complete the $12^{\text {th }}$ grade, and then qualify for a driver's license. Whereas some researchers may argue against this approach due to some social and/or economic reasons, but it is important for government authorities to have a detailed study of this proposal.

Students argue that putting classes online would significantly reduce school truancy. This means that students who have no interest in going to school can still stay at home and complete schoolwork through the Internet. Inasmuch as this is a laudable suggestion, however, several stakeholders are apprehensive about the quality of education their children would receive through online education, especially in the science-based classes. They worry about labs and hands-on learning in the science classes. Nevertheless, online education has come to stay, and will continue to expand. Therefore, it is important for school administrators and curricular planners to design research studies to ascertain how best to reduce school truancy by completing a significant part of cause syllabi through online learning, such that the online learning would not compromise the quality of education.

\section{References}

Baker, M. L. (2000). Evaluation of the truancy reduction demonstration program: Interim report. Denver: Colorado Foundation for Families and Children. Retrieved 2013 from https://www.socialworkers.org

Bazemore, G., Stinchcomb, J. B., \& Leip, L. A. (2004). Scared smart or bored straight? Testing deterrence logic in an evaluation of Police-led truancy intervention. Justice Quarterly, 21, 269-299. http://dx.doi.org/10.1080/07418820400095811

Beekhoven, S., \& Dekkers, H. (2005). Early school leaving in the lower vocational track: triangulation of qualitative and quantitative data. Adolescence, 40, 197-213. Retrieved 2013 from http://search.proquest.com/docview/195943975?accountid=28881

Brandibas, G., Jeunier, B., Clanet, C., \& Fouraste, R. (2004). Truancy, School Refusal and 
Anxiety. School Psychology International, 25, 117-126. http://dx.doi.org/10.1177/014303430 4036299

Christie, K. (2006). Counting the truants. Phi Delta Kappan Bloomington, 87, 485-486. http://dx.doi.org/10.1177/003172170608700703

Epstein, J. L., \& Sheldon, S. B. (2002). Present and accounted for: Improving student attendance through family and community involvement. Journal of Education Research, 95, 308-318. http://dx.doi.org/10.1080/00220670209596604

Fantuzzo, J., Grim, S., \& Haxan, H. (2005). Project start: an evaluation of community-wide school-based intervention to reduce truancy. School Psychology, 42, 657-667. http://dx.doi. org/10.1002/pits.20103

Fremont, W. P. (2003). School refusal in children and adolescents. American Family Physician, 68, 1555-1560. http://europepmc.org/abstract/MED/14596443

Hallfors, D., Vavea, J. L., Iritani, B., Cho, H., Khatapoush, \& S. Saxe, L. (2002). Truancy, grade point average, and sexual activity: a meta-analysis of risk indicators for youth substance use. Journal of School Health, 72, 205-211. http://dx.doi.org/10.1111/j.1746-1561. 2002.tb06548.x

Henry, K. L. (2007). Who's Skipping School: Characteristics of Truants in $8^{\text {th }}$ and $10^{\text {th }}$ Grade. The Journal of School Health, 77, 29-35. http://dx.doi.org/10.1111/j.1746-1561.2007.00159.x

Hibbert, A., \& Fogelman, K. (1990). Future lives of truants: family formation and health-related behavior. British Journal of Educational Psychology, 60, 171-179. http://dx.doi.org/10.1111/j.2044-8279.1990.tb00934.x

Ingersoll, S., \& LeBoeuf, D. (1997). Reaching Out to Youth Out of the Education Mainstream. Juvenile Justice Bulletin. Retrieved 2013 from: hppt:/eric.ed.gov/ ED408667

McCray, E. D. (2006). It's 10 a. m. Do you know where your children are? Intervention in School and Clinic, 42, 30 - 33. http://dx.doi.org/10.1177/10534512060420010501

McNear, R. B. (1999). Parental involvement as social capital: Differential effectiveness on science achievement, truancy, and dropping out. Social Forces, 78, 117-144. http://dx.doi.org/ $10.1093 / \mathrm{sf} / 78.1 .117$

Mueller, D., \& Stoddard, C. (2006). Dealing with Chronic absenteeism and its related consequences: The process and short-term effects of a diversionary juvenile court intervention. Journal of Education for students Placed at Risk, 11(2), 199-219. http://dx.doi.org/10.1207/s15327671espr1102_5

Reglin, G. (1997). Mentoring and Tutoring help (Math) program fights truancy. The Clearing House, 70, 319-324. http://dx.doi.org/10.1080/00098655.1997.10543534

Reid, K. (2004). A long-term strategic approach to tackling truancy and absenteeism from schools: The SSAG scheme. British Journal of Guidance and Counseling, 32, 57-74. http://dx.doi.org/10.1080/03069880310001648076 


\section{Macrothink}

Reimer, M. S., \& Dimock, K. (2005). Truancy Prevention in Action: Best practices and model truancy programs. Washington, DC: National Dropout Prevention Center. Retrieved 2013, from: hppt://eric.ed.gov/ED491287

Smink, J., \& Heilbrunn, J. Z. (2005). Legal and Economic implications of truancy. Washington, DC: National Dropout Prevention Center. Retrieved 2013 from hppt://eric.ed.gov/ED491290

Smink, J., \& Reimer, M. S. (2005). Fifteen Effective Strategies for Improving Student Attendance and Truancy Prevention. Washington, DC: National Dropout Prevention Center. Retrieved 2013 from: hppt://eric.ed.gov/ED485683

Stover, D. (2005). New ways, more reasons to fight truancy. Education Digest, 70, 48-51. Retrieved 2013 from: hppt://eric.ed.gov/EJ741182

Teasley, M. L. (2004). Absenteeism and Truancy: Risk, Protection, and Best Practice Implications for School Social Workers. Children and Schools, 26, 117-128. http://dx.doi.org/ $10.1093 / \mathrm{cs} / 26.2 .117$

\section{Copyright Disclaimer}

Copyright reserved by the author(s).

This article is an open-access article distributed under the terms and conditions of the Creative Commons Attribution license (http://creativecommons.org/licenses/by/3.0/). 